\title{
「研究会に行こう！」では基礎・境界ソサイエティの研究会などの様子を御紹介しています. 情報交換や懇親，新たな研究との出会いの場としてはいかがですか?
}

\section{口応用音響研究会 (EA)}

応用音響研究会 (EA) の委員長を仰せつかっております岩谷幸雄 (東北学院大学)です。 日頃より本研究会に対して御理解, 御支 援を頂き感謝申し上げます，本研究会は，「音」の収録から再生に至る電気音響变換技術をはじめとして，幅広いスペクトルを持っ ており，基礎から応用まで，様々な発表を歓迎しています，また，音声，恥覚，音楽，建築音響，超音波等隣接する分野の技術に ついても研究発表·討論の対象としており, 工学にとどまることなく，心理学，デザイン学，音楽演奏家，医学など多分野の人た ちが集まり学際的な議論が交わされています。.また, 若手・ベテランの隔てのないフランクな議論も特徵的です.

今年度は, 岡山 (5月：SP, SIP共催), 東京 (6月), 北海道 (7月：日本音響学会音楽研究会, 聴覚研究会共催), 仙台 (8月: 日本音響学会聴覚研究会共催)，京都 (10月)，広島 (11月：EMM共催)，金沢 (12月), 大阪 (1月：US共催), 東京 (3月) と 合計9回の開催が予定されています，参加する皆様の御要望に応じ, 招待講演を増やし, 若手の啓発・奨励の目的でのポスターセッ ション(12月)なども計画しています.

各会の詳細については，会告を御覽下さい，EA研究会の最新の情報は以下のURLからたどることができます，

http://www.ieice.org/ken/program/index.php?tgid=EA\&lang=I

http://asj-eacom.acoustics.jp

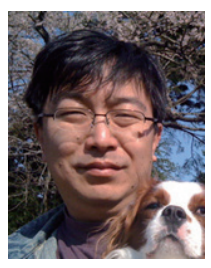

岩谷幸雄 (正員)

1993 東北大大学院工学研究科博士前期 2 年の課 程了. 同年, 秋田大助手採用. 1999 博士 (情報科学) (東北大) 取得。2000 秋田大講師，2002 東北大電 気通信研究所助教授, 2007同准教授, 2012から 東北学院大·工·教授、現在に至る。2003FIT論文 賞，2005FIT 船井ベストペーパー賞等受賞．日本音 響学会, 米国音響学会等正会員.

信頼性研究専門委員会 $(R)$ はここ数年, 年間8回の研究会を実施しております.8回を通じた共通テ一マは「信頼性一般」として, この分野に従事しておられる実務家，また企業や大学等の研究機関を問わす研究者の方々の (中間的な報告も含め) 成果発表の場 として頂くべく, 開催しております。加えて, 各回には信頼性の小分類として,「ソフトウェア」,「電気・電子機器」,「故障解析」,「通 信ネットワーク」,「光部品・電子デバイス実装」,「半導体・電子デバイス」,「信頼性国際規格」,「機構デバイス」,「計算機システ ム」などをそれぞれ設定し，各専門の方にお集まり頂いております，

信頼性と一口に申しましても, その基本技術が力バ一する範囲は上記のように広範でありますので, 各研究会と懇親会を, 様々 な方々の交流のきっかけとして御活用頂きたく, 御参加をお誘いする次第です. また本研究会は, IEEE Reliability Society Japan Chapterにおける若手の方への学術奨励賞の候補者選定機会の一つともなつておりますことを申し添えます，

最後に, 本研究会のWebページのURLはhttp://www.ieice.org/ r r/ となっております. 過去の報文集 (信学技報)などへのリ ンクもございますのでこちらも是非御訪問下さい.

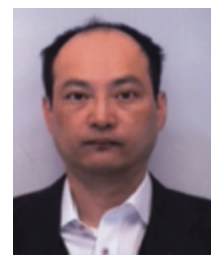

木村光宏 (正員)

1994 広島大大学院工学研究科博士課程了. 同年 鳥取大 · 工 助手, 1995 同助教授, 2001 法政大 工 ·助教授, 2007 同教授, 現在は理工学部経営シ ステム工学科所属. 主に信頼性工学に関する研究に従 事. 博士 (工学)。2013 年度から信頼性研究専門委 員会委員長. 